\title{
Farklı Miktarlarda Tüketilen Fruktozun, Vücut Ağırlığı ve Bazı Biyokimyasal Parametreler Üzerine Etkisi
}

\section{The Effect of Different Amounts of Fructose Consumption on Some Anthropometric Measurements and Biochemical Parameters}

\author{
Esra Köseler-Beyaz¹, Gül Kızıltan²
}

Geliş tarihi/Received: 13.11.2018 • Kabul tarihi/Accepted: 28.03.2019

\section{ÖZET}

Amaç: Bireylerin doğal ve/veya yüksek fruktozlu mısır şurubu olarak günlük diyetle tükettikleri farklı fruktoz miktarlarının antropometrik ölçümler, kan biyokimyasal bulguları ve diğer beslenme parametreleri ile ilişkisinin incelenmesidir.

Bireyler ve Yöntem: Çalışma, 90 (41 erkek, 49 kadın) sağlıklı birey (18-65 yll) üzerinde yürütülmüştür. Bireylerin kişisel özellikleri, fruktoz alımlarını da içeren bazı beslenme alışkanlıkları, beslenme durumları ve fiziksel aktivite durumları belirlenmiş, antropometrik ölçümleri alınmış, bazı biyokimyasal parametreleri analiz edilmiştir.

Bulgular: Bireylerin günlük diyetle fruktoz alım ortalaması $42.3 \pm 22.73$ g’dır ve erkeklerin ( $49 \pm 26.13$ g), kadınlara (36.7 \pm 17.85 g) göre daha fazla fruktoz tükettikleri belirlenmiştir ( $\mathrm{p}<0.05$ ). Bireylerin ortalama \%33.3’ünün (erkeklerin \%39'u, kadınların \%28.6’sı) günlük fruktoz alımının 50 g ve üzerinde olduğu belirlenirken, ortalama \%18.9'unda (erkeklerin \%14.6'sı, kadınların \%22.4’ü) fruktoz alımının, toplam enerji alımının \%10’undan daha fazla olduğu bulunmuştur. Günlük fruktoz alımı en yüksek olan grubun obez bireyler (BKI $=\geq 30 \mathrm{~kg} / \mathrm{m}^{2}$ ) olduğu görülmüştür. Bireylerin cinsiyete, günlük diyetle fruktoz alım miktarlarına ve günlük diyetle alınan fruktozun toplam enerjiden gelen oranlarına göre kan biyokimyasal bulgularının ortalamaları karşılaştırıldığında da, glukoz, ürik asit, total, yüksek yoğunluklu lipoprotein, düşük yoğunluklu lipoprotein kolesterol, trigliserit, serum glutamik oksaloasetik transaminaz, serum glutamik pirüvik transaminaz ve insülin değerleri açısından gruplar arası istatistiksel açıdan önemli bir farkın olmadığı saptanmıştır ( $p>0.05)$.

Sonuç: Yüksek miktarda fruktoz alımının başta obezite olmak üzere insülin direnci, bozulmuş glukoz toleransı, tip 2 diyabet, hiperlipidemi, kardiyovasküler hastalıklar, hiperürisemi, gut ve metabolik sendrom gibi hastalıklar için risk oluşturabileceği göz önünde bulundurulmalı ve günlük diyet enerjisinin \%10'dan daha azı meyve gibi doğal fruktoz kaynaklarından sağlanmalıdır.

Anahtar kelimeler: Fruktoz, yüksek fruktozlu misır şurubu, obezite, kronik hastallklar, beslenme

\section{ABSTRACT}

Aim: To determine the relation between daily dietary fructose consumption as natural and high fructose corn syrup with anthropometric measurements, blood biochemical parameters and other nutritional parameters.

1. İletişim/Correspondence: Başkent Üniversitesi, Sağlık Bilimleri Fakültesi, Beslenme ve Diyetetik Bölümü, Ankara, Türkiye • E-posta: koseler@baskent.edu.tr (ㄱ) https://orcid.org/0000-0001-7713-7871
2. Başkent Üniversitesi, Sağlık Bilimleri Fakültesi, Beslenme ve Diyetetik Bölümü, Ankara, Türkiye • E-posta: bdb@baskent.edu.tr ๑ https://orcid.org/0000-0001-5012-5838 
Subjects and Method: The study was conducted with 90 healthy individuals (41 male, 49 female) aged between 18-65 years. Demographics, nutritional habits, nutritional status and physical activity levels of the participants were determined, anthropometric measurements were evaluated, biochemical parameters were analyzed.

Results: The mean daily dietary fructose consumption was $42.3 \pm 22.74 \mathrm{~g} / \mathrm{d}$, and daily dietary consumption of fructose was higher in males than females $(49 \pm 26.13 \mathrm{~g} / \mathrm{d}$ and $36.7 \pm 17.85 \mathrm{~g} / \mathrm{d}, \mathrm{p}<0.05$, respectively). The percentages of the participants that consumed fructose daily $\geq 50 \mathrm{~g}$ and $\geq 10 \%$ of the total energy was $33.3 \%$ (39\% of males, $28.6 \%$ of females) and $18.9 \%$ (14.6\% of males, $22.4 \%$ of females), respectively. Daily fructose consumption was highest in the obese group (body mass index $\geq 30 \mathrm{~kg} /$ $\mathrm{m}^{2}$ ). When the average of blood biochemical parameters of individuals according to gender, daily diet fructose consumption and amount of from total diet energy were compared, there was no statistically significant difference between groups in terms of glucose, uric acid, total, high density lipoprotein, low density lipoprotein cholesterol, triglycerides, serum glutamic oksaloasetic transaminase, serum glutamic pyruvic transaminase and insulin values ( $p>0.05)$.

Conclusion: High fructose consumption may cause major risks for obesity, insulin resistance, impaired glucose tolerance, type 2 diabetes, hyperlipidemia, cardiovascular diseases, hyperuricemia, gout and metabolic syndrome. So, the healthy preference of fructose source in diets is fruit and the amount of safe dietary intake of fructose should be less than $10 \%$ of total energy.

Keywords: Fructose, high fructose corn syrup, obesity, chronic diseases, nutrition

\section{Gíriş}

Birçok epidemiyolojik, klinik ve deneysel çalışmalar, meyvelerin içinde doğal olarak bulunan ve meyve şekeri olarak bilinen fruktozun, besin sanayisinin en çok kullandığı tatlandırıcı haline gelmesinin ve artan alımının, obezite, insülin direnci, bozulmuş glukoz toleransı, tip 2 diyabet, hiperlipidemi, kardiyovasküler hastalıklar, hiperürisemi, gut ve metabolik sendrom gibi hastalıklarla ilintili olduğunu göstermiştir (1).

Obezite prevalansındaki artışın nedenleri arasında, besinlere eklenen şeker miktarının artması ve sükrozun yerini yüksek fruktozlu misır şurubunun (HFCS) alması gösterilmektedir (2). Yapılan çalışmalarda, fruktozun diğer şekerler gibi doyma hissi oluşturmadığına dikkat çekilmiştir. Yemeklerden sonra ortaya çlkan ve doyma hissi sağlayan en önemli iki unsur, kan glukoz ve kan insülin düzeylerinin yükselmesidir. Vücut hücrelerinin temel enerji kaynağı olan kan glukoz düzeylerinin yemekten sonra yükselmesi, kan insülin düzeylerinin yükselmesine neden olur ve kan şekeri hücrelerin içine girer. $\mathrm{Bu}$ mekanizma insanda doyma hissine neden olur ve daha fazla yemek yenmesini engeller. Fruktoz, doyma hissine katkı sağlamamasına rağmen, glukoz ile aynı enerji yüküne sahiptir. Fruktozun, iştah regülasyonunda önemli etkiye sahip yeterli insülin ve leptin salınımını sağlayamadığı ve gastrik boşalmayı hızlandırdığı bildirilmektedir. Böylece bireylerde daha geç doyma hissi oluşmakta ve daha çok yemek yeme davranışı gelişmektedir (3-5).

Yüksek fruktoz alımı vücut ağırlığı ve yağ doku artışına neden olarak insülin direncine neden olmakla birlikte, vücut ağırlığı artışından bağımsız olarak da endoplazmik stresi tetikleyerek ve beta hücre disfonksiyonuna neden olarak hepatik insülin direncine neden olmaktadır (5,6). Yapılan çalışmalarda da yüksek oranda fruktoz alımının (>50 g/gün) tip 2 diyabetin ve metabolik sendromun etiyolojik nedeni olarak tanımlanabileceği belirtilmektedir (7-9).

Yüksek fruktoz alımı, düşük yoğunluklu lipoprotein (LDL) partiküllerinin sayısını artırırken, aterojenik etki gösteren partikül ölçüsünü azaltarak (10), endotel hücrelerde adezyon moleküllerinin ekspresyonunu arttırarak ve tromboz patafizyolojisini tetikleyerek aterosklerotik sürece de neden olabilmektedir (11). Fruktoza bağlı gelişen hiperürisemi, hiperinsülinemi, aldehit oluşumu, vasküler reaktivitenin değişimi gibi durumlar da hipertansiyon ve gut gelişiminde rol oynayabilmektedir $(5,8,12)$. 
Fruktoz hepatik lipojeneze substrat sağlayarak trigliserit birikimi ve hepatik insülin direncine neden olabilmektedir. Hepatik lipit fazlalığı karaciğer trigliserit birikimine ve çok düşük yoğunluklu lipoprotein (VLDL) salgılanmasında artışa neden olmaktadır (13).

Fruktoz ile beslenme sonrası insüline karşı gelişen direnç, hepatik VLDL salınımı ile artmış plazma trigliserit düzeyleri ile ilişkilidir. Karbonhidrat ile indüklenen hipertrigliseridemi, aşırı trigliserit üretimi ve uygun olmayan trigliserit kleransının kombinasyonu sonucunda ortaya çlkmaktadır (14). Kronik yüksek fruktozlu beslenme uygulanan hayvanlarda esterleşmemiş yağ asitlerinde, karaciğer enzimlerinde artış ve hiperinsülinemi gelişmiştir $(15,16)$.

$\mathrm{Bu}$ çalışma, bireylerin günlük diyetle tükettikleri normal ve yüksek fruktoz miktarlarının antropometrik ölçümler, kan biyokimyasal bulguları üzerine etkilerinin incelenmesi amacıyla planlanıp yürütülmüştür.

\section{BİREYLER VE YÖNTEM}

Araştırma, Başkent Üniversitesi Ankara Hastanesi'nde çalışan personel ve Başkent Üniversitesi'nde okuyan öğrenciler arasından rastgele seçilen, yaşları 20-48 yll arasında olan 41'i erkek 49'u kadın olmak üzere toplam 90 sağlıklı birey üzerinde yürütülmüştür. Bu çalışma için Başkent Üniversitesi Klinik Araştırmalar Etik Kurulu'ndan 09/322 sayll ve 09/09/2008 tarihli "Etik Kurul Onayı" alınmıştır. Bireylerin demografik özellikleri ve beslenme alışkanlıkları bir anket formu ile yüz yüze görüşülerek sorgulanmıştır.

Bireylerin beslenme alışkanlıklarını ve beslenme durumunu saptamak amacıyla, besin tüketim sıklık formu, fruktozdan zengin besin çeşidini içeren fruktoz kaynakları tüketim sıklık formu ile biri hafta sonu, diğer iki günü de hafta içi bir gün olmak üzere toplam üç günlük besin tüketim kaydı araştırmacı tarafından alınmıştır. Fruktoz sıklık formundaki sorular, doğal ve yüksek fruktozlu mısır şurubu içeren besinsel kaynakların tüketim sıklık ve miktarlarını kapsamaktadır. Günlük diyetle alınan enerji ve besin ögeleri, Türkiye için geliştirilen "Bilgisayar Destekli Beslenme Programı, Beslenme Bilgi Sistemleri Paket Programı (BEBİS)" kullanılarak analiz edilmiştir. Hesaplanan enerji ve besin ögeleri verileri yaşa ve cinsiyete göre önerilen Amerika için Diyetle Referans Alım Düzeyi (Dietary Reference Intake, DRI)'ne göre değerlendirilmiştir (17).

Bireylerin boy uzunlukları (cm), vücut ağırlıkları (kg), bel ve kalça çevreleri (cm) ile vücut bileşimleri araştırmacı tarafından ölçülmüş, vücut ağırlığı ve boy uzunluğu ölçümlerinden beden kütle indeksleri (BKİ, $\mathrm{kg} / \mathrm{m}^{2}$ ) hesaplanmıştır. Beden kütle indeksi, Dünya Sağlık Örgütü (WHO) sinıflamasına göre değerlendirilmiştir (18). Bireylerin bel çevresinin erkeklerde $\geq 102 \mathrm{~cm}$, kadinlarda $\geq 88 \mathrm{~cm}$ olması yüksek risk olarak sınıflandırılmıştır (19). Bel (cm) ve kalça $(\mathrm{cm})$ çevresi ölçülerek, bel/kalça oranı (BKO) hesaplanmıştır. Bel/kalça oranının erkeklerde <0.95 ve kadınlarda $<0.85$ olması normal olarak, erkeklerde $\geq 0.95$ ve kadınlarda $\geq 0.85$ olması ise abdominal obezite göstergesi olarak değerlendirilmiştir (18).

Bireylerin yağsız vücut kütlesi, vücut yağ kütlesi ve su oranı Tanita Body Composition Analyzer UM-073 marka biyoelektriksel impedans analiz cihazı ile ölçülmüştür. Yağ yüzdesi erkeklerde $\leq 6$ ve kadınlarda $\leq 8$ “zayıf”, erkeklerde 6-15 ve kadınlarda 9-23 "normal (alt sinır)”, erkeklerde 16-24 ve kadınlarda 24-31 "normal (üst sınır)", erkeklerde $\geq 25$ ve kadınlarda $\geq 32$ “şişman” olarak değerlendirilmiştir (20).

Biyokimyasal testler, Başkent Üniversitesi Ankara Hastanesi Biyokimya Laboratuvarı'nda yapılmıştır. Çalışmaya katılan bireylerin akşam yemeği sonrası bir gecelik (10-12 saatlik) açlık sonrası sabah kan örnekleri ( $8 \mathrm{~mL}$ ) hemşire tarafindan bir kez alınmıştır. Serum total kolesterol, trigliserit (TG), yüksek yoğunluklu lipoprotein (HDL), düşük yoğunluklu lipoprotein (LDL), çok düşük yoğunluklu lipoprotein (VLDL), serum glutamik oksaloasetik transaminaz (SGOT), serum glutamik pirüvik transaminaz (SGPT), ürik asit, glukoz ve insülin değerleri Başkent 
Üniversitesi Ankara Hastanesi Merkez Biyokimya Laboratuvarı'nda analiz edilmiştir. Bireylerin kan basınçları araştırmacı tarafından kan örnekleri alınmadan önce dijital tansiyon aleti (Omron M10 Koldan Ölçer Tansiyon Aleti) ile ölçülmüştür.

\section{Verilerin İstatistiksel Değerlendirmesi}

Çalışmadan elde edilen verilerin değerlendirilmesi amacıyla SPSS (Statistical Package for Social Sciences) version 15.0 kullanılmıştır. Fruktoz alımı kuartillere (Q1-Q4) ayrılarak değerlendirilmiştir. Ayrıca, kategorik değişkenlerin değerlendirilmesinde kikare $\left(\chi^{2}\right)$ testi kullanılmıştır. Nicel değişkenlerin karşılaştırılmasında ilk olarak parametrik test koşullarının (birey sayısı ve normal dağılıma uygunluğun araştırılması) sağlanıp sağlanmadığı araştırılmıştır. İki grubun karşılaştırılması amacıyla parametrik test koşullarının sağlandığı değişkenler için Student's t testi, parametrik test koşullarının sağlanmadığı durumlarda ise Mann-Whitney U testi kullanılmıştır. Üç ve daha fazla grubun karşılaştırılmasında “Tek Yönlü Varyans Analizi” uygulanmıştır. Fruktoz alımının BKİ üzerine etkisini riske maruz kalmayanlarla karşılaştırmalı olasılığının ifadesi için de tahmini rölatif risk (OR) kullanılmıştır. Bütün istatistiksel analizlerde önemlilik düzeyi olarak $\mathrm{p}<0.05$ ve $\mathrm{p}<0.01$ olarak kabul edilmiştir.

\section{BULGULAR}

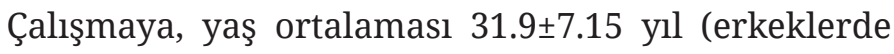
$32.0 \pm 7.50$ yıl, kadınlarda $31.7 \pm 6.93$ yll) olan 41 'i (\%45.6) erkek, 49’u (\%54.4) kadın olmak üzere toplam 90 sağlıklı birey katılmıştır. Çalışmaya katılan bireylerin \%3.3'ünün zayıf, \%55.6'sının normal ağırlıkta, \%32.2'sinin hafif şişman ve \%8.9'unun da şişman olduğu saptanmıştır (tabloda gösterilmemiş veri). Fruktoz alımı açısından cinsiyetler arasındaki farka bakıldığında, erkeklerin $(49 \pm 26.13 \mathrm{~g})$ kadınlara (36.7 \pm 17.85 g) göre daha fazla fruktoz tükettikleri belirlenmiştir $(\mathrm{p}<0.05)$ (Tablo 1).

Bireylerin cinsiyete, günlük diyetle fruktoz alımlarına ve toplam enerjinin fruktozdan gelen oranlarına göre antropometrik ve kan basıncı ölçümlerinin ortalamaları karşılaştırıldığında, gruplar arası vücut ağırlı̆̆ı, bel çevresi, bel/kalça oranı, kas ve yağ oranı, BKİ, sistolik ve diyastolik kan basınçları arasında istatistiksel açıdan önemli bir farkın olmadığı belirlenmiştir ( $p>0.05$ ) (Tablo 2).

Bireylerden BKİsi normal olanlara göre hafif şişman ve şişmanların hem günlük diyetle fruktoz alım miktarı, hem de diyet enerjisinin fruktozdan gelen oranları önemli farklılıklar göstermemiştir $(p>0.05)$ (Tablo 3). Fruktoz alımı ile BKI arasında tahmini rölatif risk bakıldığında, fruktozun günlük diyetle $>50$ g alımının BKİnin $25 \mathrm{~kg} / \mathrm{m}^{2}$ 'den büyük olma riskine katkısı istatistiksel açıdan önemli bulunamamıştır (OR=0.071, \%95 GA=0.439-2.616).

Tablo 1. Bireylerin cinsiyete göre günlük diyetle tükettikleri fruktoz ve sükroz miktarları

\begin{tabular}{lccccccccccc}
\hline \multirow{2}{*}{$\begin{array}{l}\text { Frukto ve } \\
\text { sükroz }\end{array}$} & \multicolumn{3}{c}{ Erkek (n= 41) } & \multicolumn{3}{c}{ Kadın (n= 48) } & \multicolumn{3}{c}{ Toplam (n= 90) } \\
\cline { 2 - 9 } & $\overline{\mathbf{X}}$ & SS & $\begin{array}{l}\text { En düşük- } \\
\text { en yüksek }\end{array}$ & $\overline{\mathbf{X}}$ & SS & $\begin{array}{c}\text { En düşük- } \\
\text { en yüksek }\end{array}$ & $\overline{\mathbf{X}}$ & SS & $\begin{array}{c}\text { En düşük- } \\
\text { en yüksek }\end{array}$ & $p$ \\
\hline Fruktoz (g) & 49 & 26.13 & $11.4-137.1$ & 36.7 & 17.85 & $6.9-74.6$ & 42.3 & 22.73 & $6.9-137.1$ & $* 0.010$ \\
Fruktoz (TE\%) & 7.2 & 2.71 & $2.6-12.8$ & 7.6 & 2.98 & $14.8-1.4$ & 7.4 & 2.85 & $1.4-14.8$ & 0.576 \\
Fruktoz (CHO\%) & 5.7 & 3.76 & $0.7-14.0$ & 7 & 3.98 & $0.7-14.0$ & 6.4 & 3.91 & $0.7-14.0$ & 0.145 \\
Sükroz (g) & 60.9 & 38.56 & $9.4-182.7$ & 41.8 & 25.24 & $7.1-114.2$ & 50.6 & 33.21 & $7.1-182.7$ & $* * 0.000$ \\
Sükroz (TE\%) & 9.7 & 4.44 & $2.1-20.3$ & 8.5 & 4.17 & $1.4-21.0$ & 8.8 & 4.28 & $1.4-21.0$ & 0.589 \\
Sükroz (CHO\%) & 19.8 & 7.76 & $4.4-33.0$ & 19.8 & 8.37 & $4.8-40.8$ & 19.8 & 8.06 & $4.4-40.8$ & 0.979 \\
\hline
\end{tabular}

${ }^{*} p<0.05,{ }^{* *} p<0.01$

TE\%: Toplam enerjiden gelen enerji yüzdesi, CHO\%: Karbonhidratlardan gelen enerji yüzdesi 

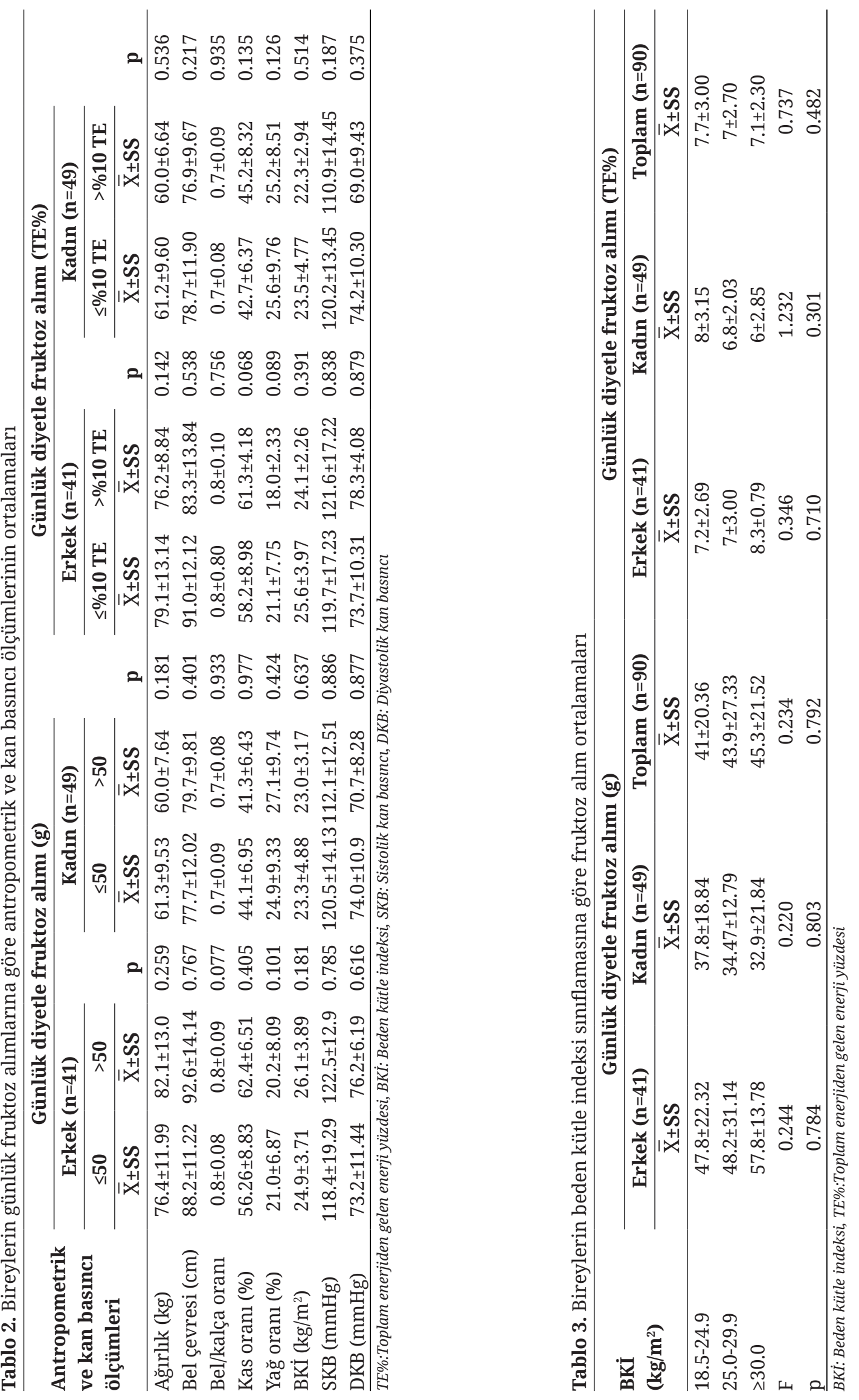

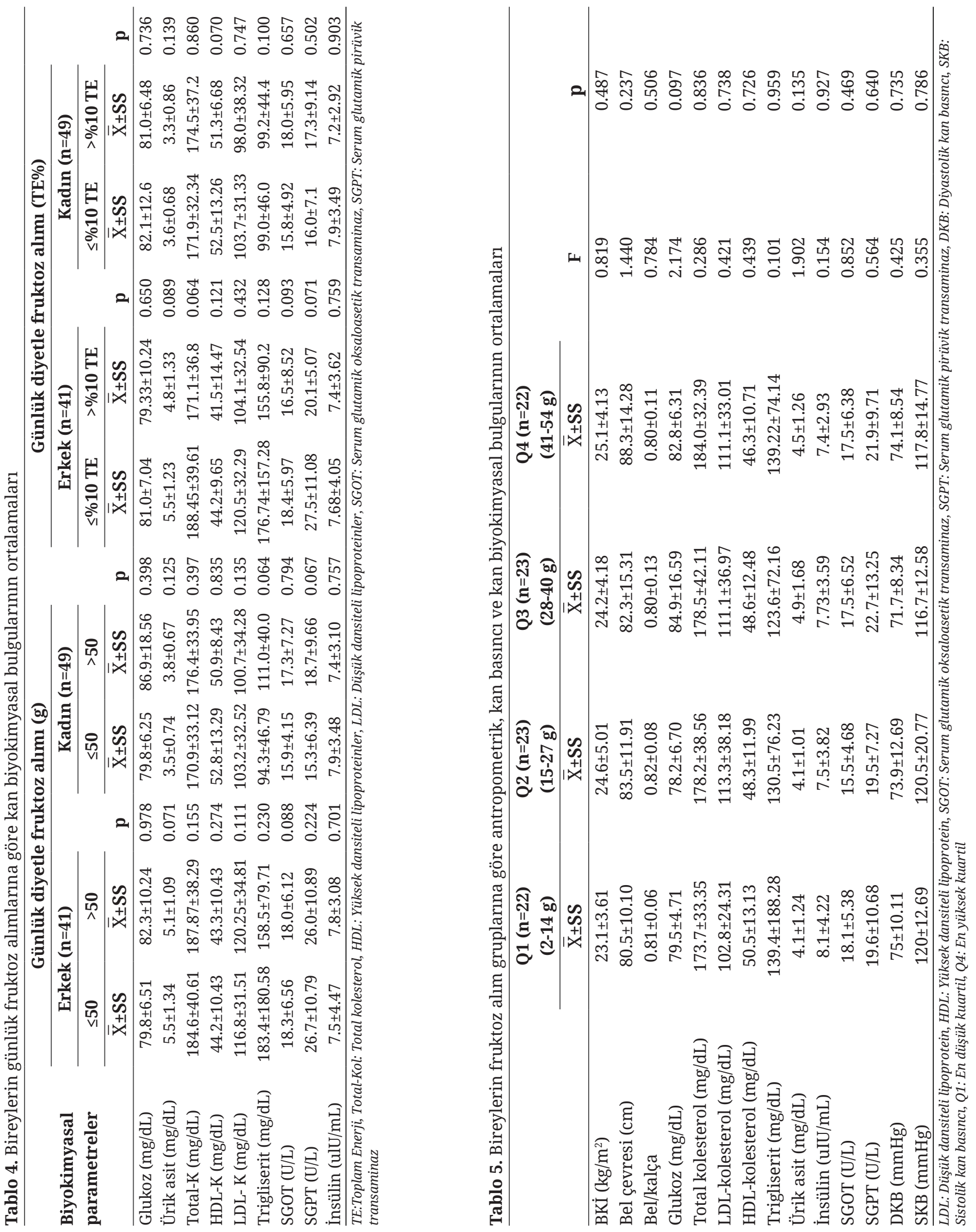
Bireylerin cinsiyet, günlük diyetle fruktoz alım miktarlarına ve toplam enerjinin günlük diyetle alınan fruktozdan gelen oranlarına göre kan biyokimyasal bulgularının ortalamaları karşılaştırıldığında da, glukoz, ürik asit, total, HDL, LDL kolesterol, trigliserit, SGOT, SGPT ve insülin değerleri açısından gruplar arası istatistiksel açıdan önemli bir farkın olmadığ 1 saptanmıştır $(\mathrm{p}<0.05)$ (Tablo 4).

Bireylerin günlük diyetle fruktoz alım gruplarına göre antropometrik, kan basıncı ve kan biyokimyasal bulgularının ortalamaları Tablo 5'te karşılaştırılmıştır. En çok fruktoz tüketen bireyler ile en az fruktoz tüketen bireylerin BKİ, bel çevresi, BKO, glukoz, total, LDL, HDL kolesterol, trigliserit, ürik asit, insülin, SGOT, SGPT, diyastolik ve sistolik kan basınçları arasında istatistiksel açıdan önemli bir farkın olmadığı saptanmıştır ( $\mathrm{p}>0.05)$.

\section{TARTIŞMA}

Doğal yiyeceklerle alımı yararlı olan fruktozun besin sanayisindeki kullanımı arttıkça, doğal olmayan yollardan fazla alınmasının obezite, insülin direnci, bozulmuş glukoz toleransı, tip 2 diyabet, hiperlipidemi, kardiyovasküler hastalıklar, hiperürisemi, gut gibi hastalıklarla ilintili olduğuna dikkat çekilmiştir (21). Literatürde daha önce Livesey ve Taylor (22) tarafindan günlük fruktoz alımı 3 ayrı grup altında sinıflandırılmıştır. Buna göre günde 0-50 g/gün arasında fruktoz alımı "orta”, 50-100 g/ gün "yüksek", 100-150 g/gün alımı ise "çok yüksek" olarak sınıflandırılmıştır. Bu sınıflamaya göre, bu çalışmadaki bireylerin günlük ortalama fruktoz alımlarinin (42.3 \pm 22.73 g/gün) “orta” düzeyde alım sınıfında yer aldığı ve bireylerin \%33.3’ünün fruktoz alımlarının >50 g/gün olduğu belirlenmiştir. Yüksek fruktoz alımının son yıllarda artışına bağlı olarak dikkat çekici obezite prevalansına neden olarak özellikle abdominal adipoz doku artışına ve adipokin salnımınında değişikliğe neden olduğu ifade edilmektedir (23-25). Bu çalışmada da günlük fruktoz alımı en yüksek olan grubun obez bireyler $\left(\geq 30 \mathrm{~kg} / \mathrm{m}^{2}\right)$ olduğu görülmektedir (Tablo 3). En az fruktoz tüketen bireylere göre, en çok fruktoz tüketenlerin, BKİ ve bel çevresi ortalamalarının istatistiksel açısından bir fark oluşturmadığı belirlenmiştir ( $p>0.05$ ) (Tablo 5.)

Yüksek miktarda alınan fruktozun yoğun olan tatlandırıcılığının insanların 'tatlı' tada bağımlılığını artırdığı böylece besin alımını artırarak vücut ağırlık kazanımına neden olduğu rapor edilmiştir (26,27). Fruktoz alımının vücut ağırlığı üzerine etkisinin incelendiği bir çalışmada, saf fruktozun veya fruktozdan zengin diyet tüketiminin insülin salgısı ve leptin üretimini baskıladığı ve bu şekilde vücut ağırlık kazanımına neden olduğu belirtilmiştir (28). Diğer bir çalışmada da toplam enerjiden gelen oranı $\% 60$ fruktoz içeren bir diyet ile beslenen farelerde leptin rezistansının geliştiği gözlenmiştir (29). Bu çalışmada, günlük diyetleri ile birlikte $>50 \mathrm{~g}$ fruktoz alan bireylerin, $\leq 50 \mathrm{~g} /$ gün fruktoz tüketen bireylere göre antropometrik ölçüm ortalamaları açısından önemli fark saptanamamıştır (Tablo 2). Bu çalışmaya katılan bireylerin günlük diyetle tükettikleri fruktoz miktarının, literatürde obezite prevalansına katkı sağlayacak fruktoz miktarına oranla düşük olmasının, antropometrik ölçümler üzerinde önemli bir farka neden olmadığı düşünülmektedir.

Fruktoz infüzyonunun plazma norepinefrin düzeylerini arttırdığı, kardiak sempatik aktiviteyi uyardığı gözlemlenmiştir (30). Yüksek fruktoz alımı sodyum geri emilimini ve reaktif oksijen türlerinin oluşumunu arttırarak hipertansiyonun gelişmesine neden olmaktadır (31). Aynı zamanda, diyetle fazla fruktoz alımınin da nova lipogenezi arttırarak hiperlipidemiye neden olduğu, lipogenezi arttırarak da dislipidemi ve obezite gelişmesinden sorumlu olduğu belirtilmektedir $(13,32,33)$. Kronik yüksek fruktoz alımı özellikle, glukozla karşılaştırıldığında gliserolün hepatik sentezini artırarak dislipidemik bir profile neden olmaktadır $(34,35)$. Stanhope et al. (13) yaptıkları bir çalışmada, fruktozun toplam enerjiden gelen oranının $\% 20$ olduğu diyetin 2 hafta, $\% 30$ olduğu bir diyetin 8 hafta ve $\% 40$ olduğu bir diyetin ise 10 hafta boyunca tüketilmesi ile açlık LDL düzeylerinin anlamlı ölçüde artış gösterdiği belirlenmiştir. Faeh et al. (36) sağlıklı erkek bireyler üzerinde yaptığı bir çalışmada, 
toplam enerjinin fruktozdan gelen oranının \%25 olduğu diyetin 6 gün alınmasından sonra bireylerin başlangıca göre açlık trigliserit ortalamalarının 2 kat arttığı belirlenmiştir. Bantle et al. (37) bu çalışmaya benzer olarak yaptıkları çalışmada da fruktozun diyet enerjisinden gelen oranı \%17 olacak şekilde hazırlanmış bir diyetin 6 hafta uygulanmasından sonra bireylerin trigliserit düzeylerinin \%32 arttığını saptamışlardır. Yapılan bir çalışmada, 2 haftadan uzun süre enerjinin \%20'si fruktozdan gelecek şekilde beslenen sağlıklı bireylerin yapılan ölçümlerinde serum açlık trigliserit ve LDL-kolesterol düzeyleri ile açlık ve tokluk apolipoprotein-B düzeylerinin arttığ ve hiperinsülineminin oluştuğu saptanmıştır (38). Thornburn et al. (15) yaptıkları araştırmada, 4 hafta süresince enerjinin \%35’i fruktozdan gelecek şekilde beslenen ratlarda insülin duyarlılığında azalma görülmüştür.

Bu çalışmada ise günlük diyetleri ile birlikte $>50 \mathrm{~g} / \mathrm{gün}$ ve toplam enerjinin fruktozdan gelen oranının $>\% 10$ olan erkek ve kadın bireylerin, $\leq 50 \mathrm{~g} / \mathrm{gün}$ ve toplam enerjinin fruktozdan gelen oranının $\leq \% 10$ olanlara göre kan lipit profili, kan basıncı, glukoz homeastazı açısından istatistiksel olarak önemli bir fark bulunmadiğı belirlenmiştir ( $p>0.05$ ) (Tablo 4). Diyetle alınan yüksek fruktoz, kan basıncı ve lipit profilinde artışa neden olmaktadır, ancak bu çalışmada bireylerin fruktoz alımının riskli sınıra ulaşmadığı için kan lipit profili, kan glukozu ve kan basıncına etki etmediği düşünülmektedir.

$\mathrm{Bu}$ çalışma sonucunda, çalışmaya katılan bireylerin günlük diyetle fruktoz alım ortalamalarının, literatürde kronik hastalıklar için risk oluşturacak fruktoz düzeylerinde olmadiğı belirlenmiştir. Çalışmaya katılan birey sayısının yetersiz olması da çalışmanın bir diğer sınırlılığı olarak düşünülmektedir. Ayrıca çalışmada kullanılan fruktozdan zengin besin çeşidini içeren fruktoz tüketim sıklık formunun araştırmacı tarafından geliştirilmiş bir form olup, her hangi bir geçerlilik ve güvenirliği söz konusunun olmaması ve fruktoz sıklık formundaki soruların, doğal ve yüksek fruktozlu mısır şurubu içeren besinsel kaynakların tüketim sıklık ve miktarlarını kapsamakla birlikte, çalışma için ortalama fruktoz tüketiminin saptanmıs olup, analiz kısmında fruktoz alım kaynaklarının ayrıca incelenmemesi de çalışmanın diğer kısıtlılıkları arasında yer almaktadır. Türkiye'de fruktoz alımını saptamaya yönelik çalışma sayısının yetersiz olması nedeniyle, bu çalışmanın yetişkin bireylerin diyetleri ile ortalama fruktoz alım miktarı açısından bir yol gösterici olacağı düşünülmektedir. Sonuç olarak, fruktozun, besinlere "Gıda Güvenliği ve Kalitesinin Denetimi ve Kontrolü” yönetmeliğine uygun olarak eklenip, Tarım ve Orman Bakanlığı tarafından denetlenmesinin, eklenen tüm içecek ve besinlerin etiketlerinde yer almasının, ev dışı beslenme tarzından uzak bir beslenme alışkanlığının tüm yaş gruplarınca benimsenmesinin ve tüketicinin bilinçlendirilmesinin fruktoz tüketiminden kaynaklanabilecek tüm riskleri ortadan kaldıracağı düşünülmektedir.

Çıkar çatışması - Conflict of interest: Yazarlar çıkar çatışması olmadığını beyan ederler. - The authors declare that they have no conflict of interest.

\section{KAYNAKLAR}

1. Tappy L, Lê KA, Tran C, Paquot N. Fructose and metabolic diseases: New findings, new questions. Nutrition. 2010;26:1044-9.

2. Korkmaz A. Fruktoz: Kronik Hastalıklar için Gizli Bir Tehdit. TAF Prev Med Bull. 2008;7:343-6.

3. Yau AMW, McLaughlin J, Maughan RJ, Gilmore W, Evans GH. The effect of short-term dietary fructose supplementation on gastric emptying rate and gastrointestinal hormone responses in healthy men. Nutrients. 2017;9(3): E258.

4. Melanson KJ, Angelopoulos TJ, Nguyen V, Zukley L, Lowndes J, Rippe JM. High-fructose corn syrup, energy intake and appetite regulation. Am J Clin Nutr. 2008;88(6):1738-44.

5. Elliott SS, Keim NL, Stern JS, Teff T, Havel PJ. Fructose, weight gain and the insulin resistance syndrome. Am J Clin Nutr. 2002;76(5):911-22.

6. Balakumar M, Raji L, Prabhu D, Sathishkumar C, Prabu P, Mohan V, et al. High-fructose diet is as detrimental as high-fat diet in the induction of insulin resistance and diabetes mediated by hepatic/pancreatic endoplasmic reticulum (ER) stress. Mol Cell Biochem. 2016;423:93-104. 
7. Levi B, Werman MJ. Long-term fructose consumption accelerates glycation and several age-related variables in male rats. J Nutr. 1998;128:1442-9.

8. Wu T, Giovvanucci E, Pischon T, Hankinson SE, Ma J, Rifai N, et al. Fructose, glycemic load and quantity and quality of carbohydrate in relation to plasma C-peptide concentrations in US women. Am J Clin Nutr. 2004;80(4):1043-9.

9. Montonen J, Järvinen $\mathrm{R}$, Knekt $\mathrm{P}$, Heliövaara $\mathrm{M}$, Reunanen A. Consumption of sweetened beverages and intakes of fructose and glucose predict Type 2 diabetes occurence. J Nutr. 2007;137:1447-54.

10. Aeberli I, Zimmermann MB, Molinari L, Lehmann R, L'allemand D, Spinas GA, et al. Fructose intake is a predictor of LDL particle size in overweight school children. Am J Clin Nutr. 2007;86(4):1174-8.

11. Cirillo P, Pellegrino G, Conte S, Maresca F, Pacifico F, Leonardi A, et al. Fructose induces prothrombotic phenotype in human endothelial cells A new role for "added sugar" in cardio-metabolic risk. J Thromb Thrombolysis. 2015;40:444-51.

12. Takagawa Y, Berger ME, Hori MT, Tuck ML, Golub MS. Long-term fructose feeding impairs vascular relaxation in rat mesenteric arteries. Am J Hypertens. 2001;14(8 Pt 1):811-7.

13. Stanhope KL, Schwarz JM, Keim NL, Griffen SC, Bremer AA, Graham JL, et al. Consuming fructosesweetened, not glucose-sweetened, beverages increases visceral adiposity and lipids and decreases insulin sensitivity in overweight/obese humans. J Clin Invest. 2009;119(5):1322-4.

14. Parks EJ, Hellerstein MK. Carbohydrate-induced hypertriacylglycerolemia: historical perspective and review of biological mechanisms. Am J Clin Nutr. 2000;71(2):412-33.

15. Thornburn AW, Storlien LH, Jenins AB, Khouri S, Kraegen EW. Fructose-induced in vivo insulin resistance and elevated plasma triglyceride levels in rats. Am J Clin Nutr. 1989;49(6):1155-63.

16. Spruss A, Bergheim I. Dietary fructose and intestinal barrier: potential risk factor in the pathogenesis of nonalcoholic fatty liver disease. J Nutr Biochem. 2009;20(9):657-62.

17. IOM. Nutrient Recommendations: Dietary Reference Intakes (DRI). Available at: https://ods.od.nih.gov/ Health_Information/Dietary_Reference_Intakes.aspx. Accessed February 4, 2019.

18. WHO. Obesity: preventing and managing the global epidemic. Report of a WHO Consultation. WHO Technical Report Series 894. Geneva: World Health Organization, 2000. Available at: http://www.who.int/ healthinfo. Accessed February 4, 2019.
19. Han TS, Van Leer EM, Seidell JC, Lean MEJ. Waist circumference action levels in the identification of cardiovascular risk factors: Prevalence study in a random sample. BMJ. 1995;311:1401-5.

20. Lee R, Nieman DC. Anthropometry. In: Lee R, Nieman DC, editors. Nutritional Assessment. New York, NY: McGraw-Hill; 2002. p. 223-288.

21. Johnson RJ, Segal MS, Sautin Y, Nakagawa T, Feig DI, Kang D, et al. Potential role of sugar (fructose) in the epidemic hypertension, obesity and the metabolic syndrome, diabetes, kidney disease. Am J Clin Nutr. 2007;86(4):899-906.

22. Livesey G, Taylor R. Fructose consumption and consequences for glycation, plasma triacylglycerol and body weight: meta-analyses and meta-regression models of intervention studies. Am J Clin Nutr. 2008;88(5):141937.

23. Ludwig DS, Peterson KE, Gortmaker SL. Relation between consumption of sugar sweetened drinks and childhood obesity: a prospective, observational analysis. Lancet. 2001;357:505-8.

24. Zubiría MG, Alzamendi A, Moreno G, Rey MA, Spinedi E, Giovambattista A. Long-term fructose intake increases adipogenic potential: evidence of direct effects of fructose on adipocyte precursor cells. Nutrients. 2016;8:198.

25. Wang Y, Beydoun MA. The obesity epidemic in the United States-gender, age, socioeconomic, racial/ethnic, and geographic characteristics: a systematic review and meta-regression analysis. Epidemiol Rev. 2007;29:6-28.

26. Bellisle F, Drewnowski A. Intense sweeteners, energy intake and the control of body weight. Eur J Clin Nutr. 2007;61(6):691-700.

27. Melanson KJ, Zukley L, Lowndes J, Nguyen V, Angelopoulos TJ, Rippe JM. Effects of high-fructose corn syrup and sucrose consumption on circulating glucose, insulin, leptin, and ghrelin and on appetite in normalweight women. Nutrition. 2007;23:103-12.

28. Havel PJ. Dietary fructose: implications for dysregulation of energy homeostasis and lipid/carbohydrate metabolism. Nutr Rev. 2005;63(5):133-57.

29. Chotiwat C, Sharp C, Teff K, Harris RBS. Feeding a highfructose diet induces leptin resistance in rats. Appetite. 2007;49:272-341.

30. Brown CM, Dulloo AG, Yepuri G, Montani J. Fructose ingestion acutely elevates blood pressure in healthy young humans. Am J Physiol Regul Integr Comp Physiol. 2008;294(3):730-7. 
31. Gordish KL, Ortiz PA, Garvin JL, Beierwaltes WH. Enhanced dietary fructose rapidly induces salt-sensitive hypertension in rats. Experimental Biology, April 2-6, 2016, San Diego. The FASEB Journal 2016;30(1):1216.

32. Jurgens H, Haass W, Castañeda TR, Schurmann A, Koebnick C, Dombrowski F, et al. Consuming fructosesweetened beverages increases body adiposity in mice. Obes Res. 2005;13(7):1146-56.

33. Dolan L, Potter S, Burdock G. Evidence-based review on the effect of normal dietary consumption of fructose on blood lipids and body weight of overweight and obese individuals. Crit Rev Food Sci Nutr. 2010;50:889-918.

34. Hallfrisch J. Metabolic effects of dietary fructose. FASEB J. 1990;4:2652-60.
35. Hannou SA, McKeown NM, Herman MA. Fructose metabolism and metabolic disease. J Clin Invest. 2018;128(2):545-55.

36. Faeh D, Minehira K, Schwarz JM, Periasami R, Seongsu $\mathrm{P}$, Tappy L. Effect of fructose overfeeding and fish oil administration on hepatic de novo lipogenesis and insulin sensitivity in healthy men. Diabetes. 2000;54:1907-13.

37. Bantle JP, Raatz SK, Thomas W, Georgopoulos A. Effects of dietary fructose on plasma lipids in healthy subjects. Am J Clin Nutr. 2000;72(5):1128-34.

38. Stanhope KL, Havel PJ. Fructose consumption: Considerations for future research on its effects on adipose distribution, lipid metabolism, and insulin sensitivity in humans. J Nutr. 2009;139(6):1236-41. 